\title{
How the CVT Specialists Working in Centres of Vocational Training Affect the Social Exclusion of People Older than 50 Years Old in Greece?
}

\author{
Kyriaki Papadaki ${ }^{1} \&$ Argyris Kyridis $^{2, *}$ \\ ${ }^{1}$ Department of Early Childhood, University of Western Macedonia, Ikoniou 2, GR-582 00 Edessa, \\ Pella, Greece. Tel: 30-694-452-9834 E-mail:kpapadaki@gmail.com \\ ${ }^{2}$ Department of Aristotle Campus, Faculty of Education, Thessaloniki, Greece \\ *Corresponding author: E-mail: akiridis@uowm.gr
}

Received: February 27, 2012 Accepted: March 15, 2012 Published: September 24, 2012

doi:10.5296/ije.v4i3.2447ＵRL: http://dx.doi.org/10.5296/ije.v4i3.2447

\begin{abstract}
The changes that took place in the sectors of society and economy worldwide had also an impact on the sector of labour. The group most affected by these changes was elder people [aged 50-65] since they were forced to immediately implement specific societal and cognitive skills. The solution against the problem of the social and employment exclusion has risen from the field of education and vocational training through the planning and materialisation of targeted programmes.

The research aims to contribute to the broader social debate of the enhancement of the system of Continuing Vocational Training [CVT] in Greece through the making of contemporary active policies to combat unemployment and social exclusion of the elder people. The chosen group for the research was the CVT Specialists of the Centres for Vocational Training [CVTs] and their relation with the social and employment excluded elder people [aged 50-65].

The current research places itself in the field of Adult Education, and more precisely in Planning, Management and Evaluation of Adult Education Programmes. The methodology used was the quantitative approach, and the formula aiming at the gathering of numerical data was the questionnaire.

The main research findings regarding the CVT Specialists self-perception for their profile has shown that their basic studies had not provided them with important help in relation with the position they held. What turned to be really important was the part of working experience. As for the procedure of planning and materialising educational programmes of vocational training on the specified social group of the elder people [aged 50-65], the findings suggested
\end{abstract}


that they didn't have sufficient knowledge or specified education. Finally, at specific correlations, there were observed some differences on the parts of profile and of planning and materialising, related with age and gender.

Keywords: Continuing Vocational Training [CVT], elder people [aged 50-65], unemployment and social, Adult Education, social exclusion, CVT specialists, the ageing population phenomenon

\section{The concept of exclusion}

Exclusion as a concept is related to the accumulation of cumulative procedures that steadily separate individuals, groups, communities and regions, leading them to an unfavourable position, compared with the prevailing values. There are three basic approaches to social exclusion, according to Pleios (1999):

1) the holistic approach, according to which employment is considered to be basic incorporating force through income, the sense of identity, and value per se, that labour and networks have to offer

2) the poverty approach, according to which the reasons for exclusion are related to low income and the lack of basic resources

3) the lower classes approach, which argues that the excluded depart from the ethical and cultural norms of the society, they are characterised by a "poverty" or "dependence" culture and they are to be blamed for the state of poverty in which they are

The interest in the current research focuses on exclusion as experienced in labour and is subsequently transferred in the society.

It argued in the literature that a contrast is formed with reference to an individual's inclusion to the social system and for this reason it constitutes a multi-dimensional and complex social phenomenon (Vlachos \& Kyritsi, 2003; Rompolis \& Dimoulas, 1998; Room, 1995; Levitas, 1998). In this sense, individuals and groups are marginalised from social, economic, political, cultural and educational life (Walker \& Walker, 1997, p.8), which results in the automatic exclusion from different aspects of the societies in which they live and are part of (Vleminckh \& Berghman, 2001, p. 34).

It is made clear from the above that social exclusion constitutes a concept directly related to the specificities and the characteristics of the contemporary era. It is deteriorated mostly due to the insufficiency of the social and state benefits (Barnes, 2002, p. 5; Room, 2000, p. 407) and at this point, the stance of the state is deemed to be crucial, as Tsiakalos suggests (1998, p. 58).

Today, many enterprises proceed on radical re-structuring, re-design their organisational charts, re-define risk management strategies and turn to Total Quality, so absolute expertise and lack of flexibility are equal to unemployment and marginalisation respectively (Pieck, 2005). 
We all know very well that nowadays the problem of professional settlement and the difficulties entailed in labour inclusion are not only a special characteristic of elder people (Mpoutsiouki, 2006) [although in this research project this is the specific case study], but it is an actual problem that many people encounter.

The prospects for Life Long Learning have to do with the fact that the individuals are capable of acquiring knowledge and at the same time develop those that they already have, regardless of time and space (McFadzean, 2001a). Furthermore, there is an attempt to deconstruct the linear system of knowledge acquisition, which was based upon the structures of the school, where the individual, after finishing its basic formation, could be employed and retain that job position for the rest of its life. However, many people will change different job positions during their professional lives and this result to the constant readjustment of the targeting of professional formation and education (Gouvias, 2003; Kazamias, 2005).

The individual seems to be exclusive responsible for organising its own life and professional settlement, and should not rest upon the actions of the organised state structures (Rontos, 2004). The individual should be motivated and activated in order not to be excluded from the labour market. Nevertheless, within a changing socioeconomic context, reenlistments in private life and complexities in its working life, it is expected to make decisions in order not to be left marginalised. (Beck, 2000; Psimitis, 2002; Tsiolis, 2005, p. 462). Unfortunately, the educational programmes for adults and executives, with the sole exception of those organised by the EU, are mostly directed to persons already holding important job positions rather than the ones that really need them. Furthermore, the everyday living problems of the part-employed and unemployed individuals do not leave any space and time for the appropriate formation (Brandsma, 2005).

The conclusion is that the main cause for the work exclusion specifically and social exclusion generally of the older people [50-65] is not related to technical obstacles posed by their age itself, but with social stereotypes that have to do with it (Brandsma, 2005). In other words, age per se should not be introduced as an excuse, but rather its outcomes, namely the lack of sufficient education, formation, and acquisition of up-to-date specified skills.

\subsection{Labour excluded and socially excluded groups: Older individuals [50-65] and the parameter of the ageing population phenomenon}

Demographic ageing at a global level is perceived to be an achievement of the humanity, according to the World Health Organisation, as referred in a relevant study (EEDE, 2007). At the same time, though, it consists one of the biggest issues that we need to deal with in the $21^{\text {st }}$ century, due to the economic and social consequences it has universally. The older persons are indeed a resource of power, neglected most of the time, with significant contribution to the working and social web.

According to the UN (I.O.BE, 2006), ageing is a positive fact, and under this consideration, active ageing was recently defined as a process that maximises the possibilities for a good health, participation and security, in order to increase life quality during the process of ageing. Within this context, the term 'active' refers to the participation of the 
elderly in various economic, social, spiritual, cultural and political activities, apart from the ability for physical action (CINTERFOR (2001).

Various structures and institutions aiming at the study of this phenomenon have established in the EU. The International Labour Organisation's mission is about the promotion of social justice and peace, as well as the protection of the rights of the elderly employees. ILO is bound to investigate issues related with demographic ageing and employment of the elderly workers. The most comprehensive and complete paper with reference to active ageing is still the 1980 N.162 Recommendation (Gklavopoulos, 2007):

"This recommendation applies to all workers who are liable to encounter difficulties in employment and occupation because of advancement in age. Each member state should within the framework of national policy to promote equality of opportunity and treatment for workers, whatever their age, and of laws and regulations and of practice of the subject, take measures for the prevention of discrimination in employment and occupation with regard to older workers. [...] Older workers should, without discriminations by reason of their age, enjoy equality of opportunity and treatment with other workers as regards, in particular: access to vocational guidance and placement services; access, taking account of their personal skills, experiences and qualifications to employment of their choice; access to vocational training facilities; and employment security for permanent occupation."

\subsection{The relationships between vocational training and older individuals (50-65)}

In the contemporary labour world, we are facing a rapid depreciation of the worker's knowledge that ultimately hampers the practice of a specific profession during their working life. Taking under consideration the technological changes in the production areas, in due time there would be fewer individuals able to avoid an in depth reformation of their professional knowledge and redirection to continuous professional formation during their professional life (Koukiadis, 2008). Continuous vocational training is then to become a basic parameter of professional evolution for the workers until the end of their career. The hypothesis that vocational training and ageing are related is based upon two facts, the rapid change in the methods of production and organisation taking place in working space, and the rapid depreciation of older persons' knowledge (CEDEFOP, 2002).

From all the above it becomes obvious that the position of the Director of Training in the Centres Vocational Training [CVTs] in planning and implementing training programmes, as well as in the choice and total support of the group to be trained, is something more than important in order to avoid labour and social exclusion. Nevertheless, most systems of continuous vocational training, such as the CVTs, seem to favour the young person into the process of introduction in the job market so far, instead of facilitating promotion for those in the second half of their working career (Glavopoulos, 2006).

From country to country, vocational training is provided in different ways. It could be provided within the working area (Jarvis, 2003), but it can also be a more general concept, provided within all learning procedures and all ages, and with both as typical and atypical activities (Kotsiki, 2003). Adult persons do return in the learning procedure (Kokkos, 2005b). 
By returning, they request expertise in knowledge and practical learning (Jarvis, 1995). For this reasons, there have been established many structures and institutions for planning, organising and putting into action various vocational training programmes for adults, in a variety of fields.

On the one hand, the production units within the labour market are in need of human resources with very specific characteristics. On the other hand, Education and training are not sufficiently prepared to answer these needs (Bennell, 1999). Bangemann report (1994, p. 5) stresses, "this revolution adds extremely more new capabilities in human intelligence and constitutes an alternative which changes the way we work and live together". Education and training would be the crucial factors in this transition. This scenario illustrates what is perceived to be the future prospects of Life Long Learning, and which characterises most components of the economically competitive population in Europe. This procedure, the transferring from education to the rules of professional occupation, is what creates the relationship between supply and demand, with demand forming supply being a usual phenomenon (Georgiakodis \& Tzanetea, 2002).

\subsection{What the CVTs are?}

Continuous Vocational Training presupposes that an initial formation has already taken place, and aims at the learning new knowledge and technical means, or enhancing of the existing, through the spectrum of a tireless procedure. For this reason, both an initial and a continuous vocational training are needed for the working population, in order to make it capable of introduction to the demands of the new society (Vergidis, 2002). In addition, it also functions as a source of optimism for all the working population in need of continuous training in order to stay active in the labour market (Knowles, Holton \& Swanson, 1998). CVTs are specific structures with exclusive field of action "the provision of continuous vocational training as well as any activities related to it - studies, lectures, conferences, educational handbooks for the trainees, participation in integrated programmes, promotion and support of employment" (Act 230/21.2.2005).

In order to investigate the CVTs typology, they are divided in four categories: CVTs accountable to Local Authorities; CVTs under the control of the private sector [terciery education institutions]; private companies; and CVTs accountable to the societal sector and NGOs (Karalis, 2005b, p. 338). The majority of CVTs in Greece can be found in the private sector (Eustratoglou, 2003). With reference to the above typology, which is the one used in this research project, we can draw any conclusions.

\subsection{The profile of CVTs Specialists}

The various CVT programmes enable the trainees to be kept informed and upgrade their professional knowledge, so either to maintain their current job position, or to be promoted in their occupation. As a consequence, the human resources of a CVT, and especially the Specialist of Training, need to posses a variety of skills in adult education (Vainas \& Economou, 2007) as well as professional-educational experience, since the CVT specialist is the one reliable for designing and putting into action programmes of training based upon the 
philosophy of continuous vocational training. Under these lines, apart from objective skills that CVT specialists need to posses, very important role also plays their self-perception about these skills. This is important because the perception that CVT specialists have for themselves and their skills very often leads to mistakes in planning and implementing the CVT programmes, since they cannot identify their weaknesses and improve them.

It is a fact that the structures and the procedures through which specialised personnel could be educated in order to fill these positions, have not yet been developed. The institutions that did carry out such training programmes from time to time include, among others, the General Secretariat for Adult Education, banks and the General National Confederation of Workers [GSEE] (Kokkos, 2005, p. 135).Indicative of the situation is the fact that adult Education does not consist a distinct discipline. One major reason for not been recognised as a distinct profession has to do with the fact that most of the personnel involved in adult education comes from a great variety of educational backgrounds and this is not their basic but their supplementary professional activity (Jarvis, 2003). Consequently, most specialists acquire their knowledge and expertise in adult education through postgraduate studies or certified training, but without having their basic degree in the field. However, even if they do pursue expertise in adult education through a master degree, still they cannot acquire the legal status of exercising the profession by the state, in order to practice adult education as their primary occupation. The lack of opportunities for full-time employment that derives from this lack of professional rights for the graduates of these fields of study also suggests the weaknesses that in the structures where various programmes for adult training are planned and implemented. Indicative of this situation is the fact that when the Bill for the Regularisation of Life Long Learning was submitted to the Parliament in 2005, it did not include the specific formal and substantive qualifications required in order to be eligible for employment in positions directly related with adult education.

Especially for the CVT structures, the qualifications required for the Specialists and Directors of Training are limited to the possession of a bachelor degree in any field and the previous professional experience in adult education. The lack of a complete and concrete legislative framework clearly suggests that eligible for the position of the CVT specialist is anyone who has a bachelor degree and relative experience.

However, adult education constitutes a distinct discipline due to its special characteristics and so its specialists need to fulfil specific requirements. These include: scientific knowledge; knowledge in education, in order to built upon existing experience; societal knowledge, in order to be able to treat the adult learner within its working and social environment; and institutional knowledge, in order to be able to use the institutional framework get the best out of various funding programmes. These suggestions are also supported by a research study undertaken by the Sociology Department of the University of Crete about continuous education in Greece. The results of this study confirm the problems that derive from the incomplete psychopedagogic training (Papaioannou, 2004).

Apart from the need for formal qualification, the specialised personnel involved in adult education, in this instance the CVT specialists, need also to possess social skills, according to 
Jarvis (2003). Adult learners are not just educational entities, but also economic, social, political, psychological and cultural, and should be treated as such.

At this point it should be stressed that it would consists a major omission the neglect of studies within the field of Gender Studies that discuss the profile of the vocational training and adult education specialist. Mee and Wiltishire (1978, p. 59) suggested that men tend to hold higher levels in the job hierarchy, compared to women. Similar findings are stressed in another study, according to which two thirds of the training instructors in adult education at a local level are women (Martin, 1981, p. 122). Finally, Jarvis (2003,p. 238) refers to a study undertaken by Hutchinson (1970), which suggests that $87 \%$ of the Directors at the highest level of adult education, in University Departments, are male.

It is fact that the role of the CVT specialists in planning and implementing various programmes is crucial for the educational results upon the learners. As referred previously, the specialist on adult education does not have yet distinct characteristics but still needs to have the total supervision of them. However, these persons that exercise both educational and administrative roles in the context of adult education, have to teach a variety of subjects. Nevertheless, in this profession it is not easy to distinguish between the role of a tutor and a manager (Jarvis \& Chadwick, 1994, p. 6436). So they need to know both how to plant and evaluate programmes and at the same time to teach the training tutors, since usually the tutors in adult education do not have the teaching experience required due to the fact that they have only exercised their profession outside adult education (Streuner \& Tuijnman, 1994, p. 1309).

In general, the role of the CVT specialist can be summarised to the following responsibilities:

- To plan programmes through which the older people can acquire meta-cognitive skills (Duke, 1989, p. 365).

- To encourage the group motivate internally and externally the participants (Efkleidis, 1997).

- To have the sensitivity and communicational abilities needed in order to infiltrate the group and report its problems without identifying himself with it (Kokkos, 2003, p. 208).

- Not be biased and attached to old approaches, but receptive to new methods and techniques (Raptis \& Rapti, 2003).

- To respect and support the profile and culture of a specific group (Jaques, 2004, pp. 49-50).

- To be updated on the situation in the labour market in order to focus on the type of training and the process of promotion in employment (Koutsonikos \& Katsigianni, 2003, pp. 60-61).

\section{The Research}

The study took place in the Prefecture of Thessaloniki. The objects of the study were the Specialists belonging to national and regional action CVTs in East and West Thessaloniki, in 
Thessaloniki city centre, and in the semi-urban and rural areas of Thessaloniki Prefecture. Analysis of the perceptions of the CVT specialists in the particular Prefecture could provide interesting insights for the planning and implementation of vocational training programmes targeted to the 50-65 age group.

The purpose of the research is to record, analyse and present the perceptions of the CVT specialists in Thessaloniki Prefecture. More precisely, there will be an effort to evaluate the vocational programmes' targeted at people aged 50-65 implementation through the investigation of the perceptions of CVT specialists in the planning and implementing process. The research questions are the following: (a) Whether the specialists perceive themselves in possession of substantive skills, apart from formal qualifications, that enable them to plan and implement the programmes; and (b) Whether planning and implementation of these programmes take under consideration the target age group in order to initially join the programmes and eventually enter the labour market. The specific purposes of the research are the following:

1) To investigate whether the CVT specialists' profile [gender, age, education, professional and educational experience] has an impact on their perception of their role during planning and implementation of the programmes, as well as in choosing the participating trainees.

2) To evaluate the degree of satisfaction of the Directors of Training and the Heads of the Branches with regard to the range and quality of the research undertaken by institutionalised structures in issues of adult education.

3) To research whether the aim of these programmes is the distribution of socio-cognitive skills to older age individuals, threatened by social exclusion, in learning to learn over time.

4) To trace the divergence between the institutional context and the actual programmes.

\subsection{The sample and the collection of the data}

The sample of the study is the national and regional action CVT specialists in East and West Thessaloniki, in Thessaloniki city centre, and in the semi-urban and rural areas of Thessaloniki Prefecture. More precisely, initially 64 CVTs were contacted, but only 58 of them agreed to take part in.

The study took place during the time between March and May 2009. The research tool that was most useful in order to answer the research questions was the questionnaire. The questionnaire was designed to explore the CVT specialists' perceptions about role self-interpretation, planning, implementing and evaluating continuous vocational training programmes, as well as the selection of the participants threatened by social exclusion in the programmes.

The scale chosen for the construction of the questions was a five-point Likert scale. The questionnaire in its final option included 28 questions divided in three parts. The first part contained demographic evidence; the second part explored the profile, and the third part 
constituted a multi-themed unit that investigated the CVT specialists' opinions about planning and implementation of vocational training programmes targeted to individuals aged 50-65. The total 28 questions were divided as follows: 5 questions in the first part; 5 question in the second part; and 18 questions in the third part. The third part was further divided in three units. The first unit referred to programme planning and contained 8 questions. The second unit was about participant selection and contained 4 questions. Finally, the third unit was relevant with the programme implementation and contained 6 questions.

\subsection{Demographics}

Table 1: Distribution of CVT according to their type

\begin{tabular}{lcccc}
\hline \multicolumn{1}{c}{ Type of CVT } & Public & Private & $\begin{array}{c}\text { Local } \\
\text { authorities }\end{array}$ & Total \\
\hline National range & 5 & 38 & 0 & 43 \\
Regional & 0 & 11 & 4 & $(74 \%)$ \\
Range & 5 & 49 & 4 & $(26 \%)$ \\
Total & $(8.6 \%)$ & $(84.5 \%)$ & $(6.9 \%)$ & 58 \\
\hline
\end{tabular}

The gender analysis does not suggest any significant difference about the selection of men and women in these executive positions. From the 58 individuals taking part in the study, 32 are en and 27 are women, indicating that women perform almost equally well with men in position of responsibility and decision-making.

The age of the sample ranges from 29 to 57 years old. As Table 2 indicates, the average age is 42.9 years old, with a standard deviation of almost 8 years (7.68). The median is 42.5 years, and when combined with the average and the symmetry indicator of $0.09<|1.96|$ we can see that we have an almost normal distribution. (Psarou \& Zafiropoulos, 2003), where $25 \%$ of the youngest specialists is below 37 years and $25 \%$ of the older specialists is above 48 years. A $50 \%$ of the specialists staking part in the study ranged were between 37 and 48 years old.

Table 2: Distribution of age

\begin{tabular}{llllllllll}
\hline $\mathrm{N}$ & $\begin{array}{c}\text { Average } \\
\text { age }\end{array}$ & $\begin{array}{l}\text { Median } \\
\text { Age }\end{array}$ & $\begin{array}{l}\text { Standard } \\
\text { Deviation }\end{array}$ & $\begin{array}{l}\text { Asymmetry } \\
\text { Index }\end{array}$ & Min & Max & $25 \%$ & $50 \%$ & $5 \%$ \\
\hline 58 & 42.9 & 42.5 & 7.68 & 0.09 & 29 & 57 & 36.75 & 42.5 & 48.25 \\
\hline
\end{tabular}

In order to calculate the educational level of the specialists they were requested to answer questions about their level of study, their field of study, knowledge of foreign languages, and computer skills. Table 3 suggests that the majority of the participants in the study hold a University [AEI] degree, while only 6 individuals come from higher technological institutes [TEI]. Divided in the field of study, we can see that out from 52 
participants holding a University degree, the 26 (44.8\%) come from an Arts \& Humanities educational background, 13 participants $(22.4 \%)$ come from the Social Sciences \& Business, and 19 participants $(32.8 \%)$ hold a degree in the Sciences \& Life Sciences. The respective numbers for TEI graduates are 0 from the Arts \& Humanities, 2 from the Social Sciences \& Business, and 4 from Sciences \& Life Sciences. Furthermore, very few of the participants hold postgraduate taught degree [Master] and even fewer hold a doctoral degree [PhD etc].

Table 3: Distribution of education

\begin{tabular}{lllll}
\hline Field of Study & $\begin{array}{l}\text { Arts } \\
\text { Humanities }\end{array}$ & $\begin{array}{l}\text { \& Social } \\
\text { Sciences } \\
\text { \& Business }\end{array}$ & $\begin{array}{l}\text { Sciences \& } \\
\text { Life } \\
\text { Science }\end{array}$ & Total \\
\hline Institution & & & & \\
\hline TEl Graduate & 0 & 2 & 4 & 6 \\
AEI Graduate & 26 & 11 & 15 & $(10.3 \%)$ \\
Total & 26 & 13 & 19 & $(89.7 \%)$ \\
& $(44.8 \%)$ & $(22.4 \%)$ & $(32.8 \%)$ & $\mathbf{5 8}$ \\
\hline
\end{tabular}

When it comes to the knowledge of foreign languages we observe that most people have qualifications in English language, while a great number of the also speak a second foreign language. More precisely, 44 participants speak English, 9 of them speak French, and 15 speak German. Furthermore, all the CVT specialists have computer skills, which can bee seen in Table 4:

Table 4: Distribution of computer skills

\begin{tabular}{cccc}
\hline $\mathbf{1}$-3 years & $\mathbf{3 - 5}$ years & More than 5 years & Total \\
\hline 3 & 14 & 41 & 58 \\
\hline
\end{tabular}

In order to calculate professional experience, three criteria were taken into consideration: educational experience; professional [administrative] experience; and professional experience working with older individuals. The participants have an average educational experience of about 8 years (7.76). Half of them have an experience ranging from 6 years to 20 years. The positive symmetry indicator suggests that extreme observations can be found with a big amount of professional experience. Furthermore, $50 \%$ of the sample has an educational experience ranging between 4 and 11 years. Professional experience in administrative positions ranges from 1 to 19 years. An estimated 50\% of them have an experience ranging from 2 to 9 years, with an average of 7 years (6.91-5.49). Finally, the average professional experience in older people [50 to 65 years] is almost 6 years $(5.71)$. However, $50 \%$ of them have an experience with a range from 2 to 8 years. Maximum experience observed is 18 years. Nevertheless, according to the asymmetry indicator those with an experience of any years are very few. 


\subsection{The CVT Specialist Profile}

The profile of the CVT specialists was analysed through specific questions. More precisely, in the question whether their basic studies [first degree, postgraduate studies, further training] prepared them properly for issues linked to equality in opportunity, the CVT specialists answered negatively, with 79\% (46 participants) answering "No", and only 21\% (12 participants) answering that their basic studies did help. This information is considered very important, since it verifies that the institutional framework for employment these positions does not require specified studies in the field but general formal qualifications.

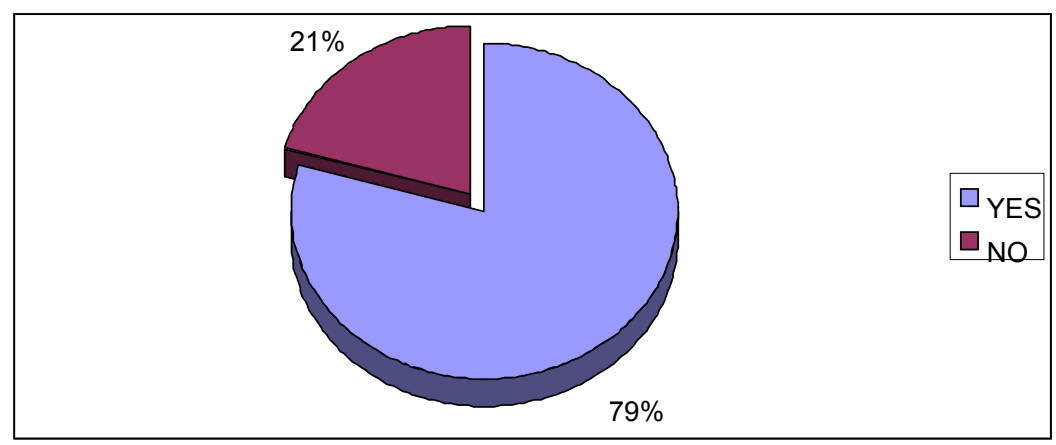

Figure 1

In Figure 2 we can see the participants' answers in the question if they had attended any training seminars on related issues during their employment in the CVTs. The specialists answer that:

- With regard to adult education issues, 46 participants $(79.3 \%)$ out of 58 had attended at least one seminar in the scientific field of adult education, with 12 participants answering negatively.

- With regard to older people (50-65) training, 49 participants (85\%) answered that they had not attended any seminars on this particular age group, while only 9 participants $(16 \%)$ had attended such seminars. 


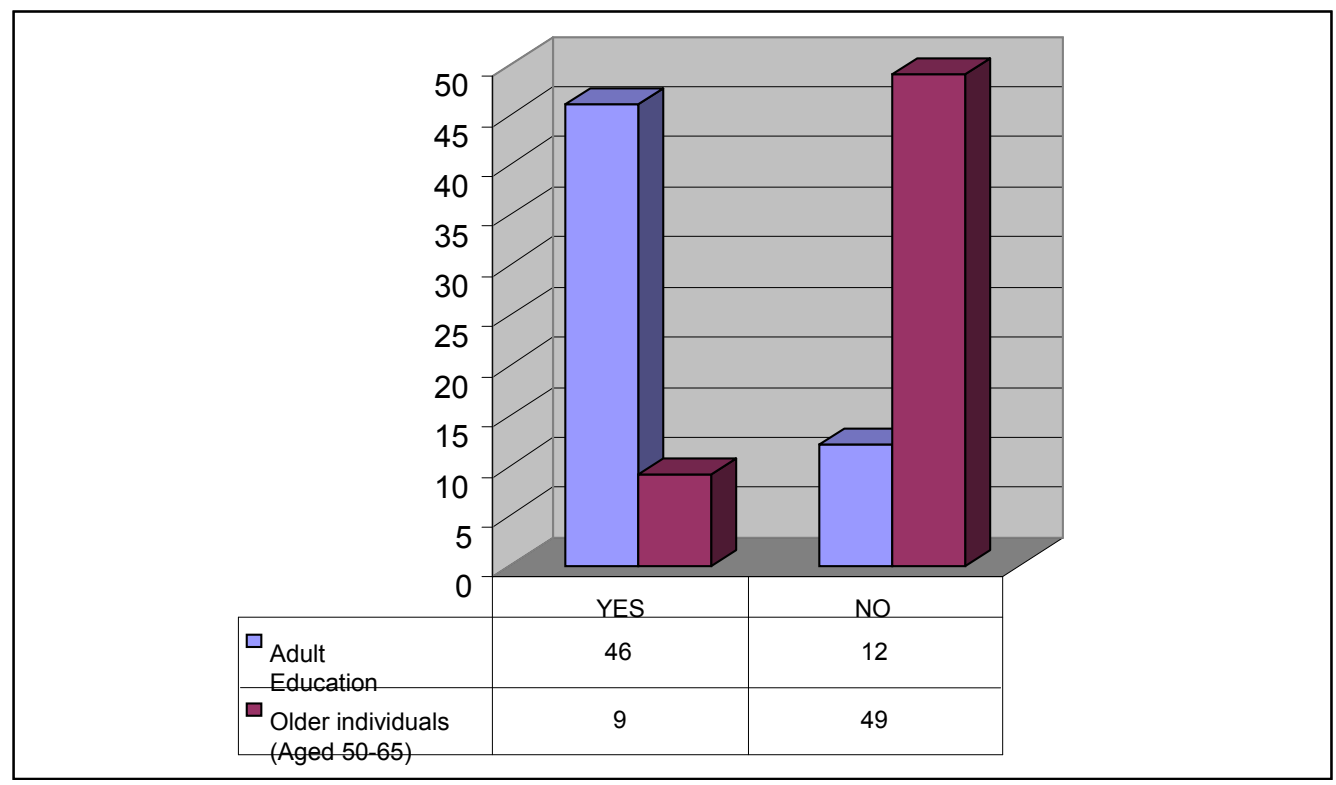

Figure 2

The answers in the final question can be found in Table 5. As we can see from the Table, 53 participants (92\%) consider cooperation with other CVT specialists as positive, since they have both educational and professional experience on issues related to special social groups, and their contribution is considered to be important. Only 5 participants $(8.6 \%)$ consider this collaboration insignificant. Some possible reasons for this negative answer may have to do with bad former experience in cooperation, with conflicts and poor personal relations. Furthermore, 10 participants answered that they had cooperated with 1 person, 4 participants with 2 persons, 4 participants with 3,9 of them with 4, and only 3 had cooperated with 5 persons.

Table 5: Cooperation with other CVTs

\begin{tabular}{lccccc}
\hline & $\begin{array}{c}\text { Not at } \\
\text { all }\end{array}$ & $\begin{array}{l}\text { Very } \\
\text { little }\end{array}$ & $\begin{array}{c}\text { Enough } \\
\text { Much }\end{array}$ & $\begin{array}{c}\text { Very } \\
\text { Musolutely }\end{array}$ & A \\
$\begin{array}{l}\text { 5.: Do you believe that your work is } \\
\text { facilitated through cooperation with other }\end{array}$ & 0 & 5 & 12 & 30 & 11 \\
$\begin{array}{l}\text { CVT specialists that have an educational or } \\
\text { professional experience in socially }\end{array}$ & $(0 \%)$ & $(8.6 \%)$ & $(20.7 \%)$ & $(51.7 \%)$ & $(19 \%)$ \\
vulnerable groups? & & & & & \\
\hline
\end{tabular}

\subsection{Multi-themed unit}

In the analysis for the coefficient of reliability, Cronbach's Alpha was estimated 0.884 .

\subsubsection{Planning Analysis}

As we can see in Table 6, the participants had a positive attitude towards questions 2, 3, 5 and 7 , with the average being above 3. This indicates that the centre of gravity of the 
answers was between 3 "enough" and 4 "very much". This is also verified by the median, which shows that in four cases half of the participants answered above 4 "very much". In the rest of the questions, 1,4 and 6 , we have an average almost 2.5 , which suggests that the participants are not very optimist, since their answers rest mostly below 3 (median), which indicates a neutral stance. Cronbach's Alpha coefficient for the planning unit was estimated 0.772 , which suggests that the degree of reliability in this unit is very satisfying.

Table 6: Statistical Parameters for "Planning",

\begin{tabular}{|c|c|c|c|c|c|c|c|c|c|c|}
\hline & Planning & $\begin{array}{l}\text { Not at } \\
\text { all }\end{array}$ & $\begin{array}{l}\text { Very } \\
\text { few }\end{array}$ & $\begin{array}{l}\text { Enoug } \\
\text { h }\end{array}$ & $\begin{array}{l}\text { Very } \\
\text { much }\end{array}$ & $\begin{array}{l}\text { Extre } \\
\text { mely }\end{array}$ & Mean & Median & $\begin{array}{l}\text { standard } \\
\text { deviation }\end{array}$ & $\begin{array}{l}\text { Skewness } \\
(\gamma)\end{array}$ \\
\hline 1 & $\begin{array}{l}\text { Do you believe that the } \\
\text { way in which } \\
\text { programmes are } \\
\text { publicised leaves } \\
\text { space for initiatives in } \\
\text { the programme } \\
\text { planning? }\end{array}$ & $\begin{array}{l}0 \\
(0 \%)\end{array}$ & $\begin{array}{l}25 \\
(43 \%)\end{array}$ & $\begin{array}{l}17 \\
(29 \%)\end{array}$ & $\begin{array}{l}16 \\
(28 \%)\end{array}$ & $\begin{array}{l}0 \\
(0 \%)\end{array}$ & 2,84 & 3,0 & 0,83 & 0,30 \\
\hline 2 & $\begin{array}{l}\text { Do you take under } \\
\text { consideration during } \\
\text { programme planning } \\
\text { the specific needs in } \\
\text { the labour market? }\end{array}$ & $\begin{array}{l}0 \\
(0 \%)\end{array}$ & $\begin{array}{l}2 \\
(3 \%)\end{array}$ & $\begin{array}{l}14 \\
(24 \%)\end{array}$ & $\begin{array}{l}21 \\
(36 \%)\end{array}$ & $\begin{array}{l}21 \\
(36 \%)\end{array}$ & 4,05 & 4,0 & 0,87 & $-0,44$ \\
\hline 3 & $\begin{array}{l}\text { Do you take under } \\
\text { consideration during } \\
\text { programme planning } \\
\text { the educational needs } \\
\text { of the various social } \\
\text { groups? }\end{array}$ & $\begin{array}{l}1 \\
(2 \%)\end{array}$ & $\begin{array}{l}9 \\
(16 \%)\end{array}$ & $\begin{array}{l}17 \\
(29 \%)\end{array}$ & $\begin{array}{l}18 \\
(31 \%)\end{array}$ & $\begin{array}{l}13 \\
(22 \%)\end{array}$ & 3,57 & 4,0 & 1,06 & $-0,23$ \\
\hline 4 & $\begin{array}{l}\text { Are you satisfied with } \\
\text { the quality and range } \\
\text { of the research } \\
\text { undertaken by the } \\
\text { qualified institutions } \\
\text { with regard to the } \\
\text { needs of the labour } \\
\text { market? }\end{array}$ & $\begin{array}{l}5 \\
(9 \%)\end{array}$ & $\begin{array}{l}12 \\
(21 \%)\end{array}$ & $\begin{array}{l}31 \\
(53 \%)\end{array}$ & $\begin{array}{l}10 \\
(17 \%)\end{array}$ & $\begin{array}{l}0 \\
(0 \%)\end{array}$ & 2,79 & 3,0 & 0,83 & $-0,53$ \\
\hline 5 & $\begin{array}{l}\text { Do you believe that } \\
\text { during the publication } \\
\text { of the training fields } \\
\text { the needs of the labour } \\
\text { market are taken under } \\
\text { consideration? }\end{array}$ & $\begin{array}{l}0 \\
(0 \%)\end{array}$ & $\begin{array}{l}1 \\
(2 \%)\end{array}$ & $\begin{array}{l}11 \\
(19 \%)\end{array}$ & $\begin{array}{l}29 \\
(50 \%)\end{array}$ & $\begin{array}{l}17 \\
(29 \%)\end{array}$ & 4,07 & 4,0 & 0,75 & $-0,38$ \\
\hline 6 & $\begin{array}{l}\text { Do you consider state } \\
\text { briefing with regard to } \\
\text { issues of social } \\
\text { exclusion sufficient? }\end{array}$ & $\begin{array}{l}9 \\
(16 \%)\end{array}$ & $\begin{array}{l}16 \\
(28 \%)\end{array}$ & $\begin{array}{l}27 \\
(47 \%)\end{array}$ & $\begin{array}{l}6 \\
(10 \%)\end{array}$ & $\begin{array}{l}0 \\
(0 \%)\end{array}$ & 2,52 & 3,0 & 0,88 & $-0,29$ \\
\hline 7 & $\begin{array}{l}\text { Up to which extend do } \\
\text { you cooperate with } \\
\text { other groups and } \\
\text { agencies aiming at the } \\
\text { same target group } \\
\text { during programme } \\
\text { planning? }\end{array}$ & $\begin{array}{l}0 \\
(0 \%)\end{array}$ & $\begin{array}{l}3 \\
(5 \%)\end{array}$ & $\begin{array}{l}15 \\
(26 \%)\end{array}$ & $\begin{array}{l}19 \\
(33 \%)\end{array}$ & $\begin{array}{l}21 \\
(36 \%)\end{array}$ & 4,00 & 4,0 & 0,92 & $-0,42$ \\
\hline
\end{tabular}




\section{Macrothink}

In Table 6 , in 6 out of 7 questions, we have a negative indicator of asymmetry. That means that the majority of the extreme observations is below the average, while in question 1 the indicator is positive, meaning that the majority of the extreme observations is above the average.

\subsubsection{Selection Analysis}

Table 7: Statistical parameters for "Selection"

\begin{tabular}{|c|c|c|c|c|c|c|c|c|c|c|}
\hline & Selection & $\begin{array}{l}\text { Strongly } \\
\text { Disagree }\end{array}$ & Disagree & Neutral & Agree & $\begin{array}{l}\text { Strongly } \\
\text { Agree }\end{array}$ & Mean & Median & $\begin{array}{l}\text { Standard } \\
\text { Deviation }\end{array}$ & Skewness $(\gamma)$ \\
\hline 1 & $\begin{array}{l}\text { Is } \\
\text { correspondence } \\
\text { of qualification } \\
\text { to the field of } \\
\text { training a } \\
\text { criterion for } \\
\text { selection? }\end{array}$ & $\begin{array}{l}0 \\
(0 \%)\end{array}$ & $\begin{array}{l}7 \\
(12 \%)\end{array}$ & $\begin{array}{l}19 \\
(33 \%)\end{array}$ & $\begin{array}{l}25 \\
(43 \%)\end{array}$ & $\begin{array}{l}7 \\
(12 \%)\end{array}$ & 3,55 & 4,0 & 0,86 & $-0,17$ \\
\hline 2 & $\begin{array}{l}\text { The criterion } \\
\text { for selection is } \\
\text { the achievement } \\
\text { of homogeneity } \\
\text { or the } \\
\text { educational } \\
\text { qualifications of } \\
\text { the group? }\end{array}$ & $\begin{array}{l}0 \\
(0 \%)\end{array}$ & $\begin{array}{l}7 \\
(12 \%)\end{array}$ & $\begin{array}{l}21 \\
(36 \%)\end{array}$ & $\begin{array}{l}22 \\
(38 \%)\end{array}$ & $\begin{array}{l}8 \\
(14 \%)\end{array}$ & 3,53 & 4,0 & 0,88 & $-0,03$ \\
\hline 3 & $\begin{array}{l}\text { Does the } \\
\text { interview play an } \\
\text { important role } \\
\text { during the } \\
\text { selection of the } \\
\text { participants? }\end{array}$ & $\begin{array}{l}3 \\
(5 \%)\end{array}$ & $\begin{array}{l}16 \\
(28 \%)\end{array}$ & $\begin{array}{l}18 \\
(31 \%)\end{array}$ & $\begin{array}{l}12 \\
(21 \%)\end{array}$ & $\begin{array}{l}9 \\
(16 \%)\end{array}$ & 3,14 & 3,0 & 1,15 & 0,16 \\
\hline 4 & $\begin{array}{l}\text { Is the participant } \\
\text { selected } \\
\text { according to his } \\
\text { ability to } \\
\text { compete equally } \\
\text { in the } \\
\text { educational } \\
\text { process and } \\
\text { training? }\end{array}$ & $\begin{array}{l}0 \\
(9 \%)\end{array}$ & $\begin{array}{l}14 \\
(24 \%)\end{array}$ & $\begin{array}{l}18 \\
(31 \%)\end{array}$ & $\begin{array}{l}20 \\
(34 \%)\end{array}$ & $\begin{array}{l}6 \\
(10 \%)\end{array}$ & 3,31 & 3,0 & 0,96 & 0,07 \\
\hline 5 & $\begin{array}{l}\text { Up to which } \\
\text { extend do you } \\
\text { cooperate with } \\
\text { groups and } \\
\text { agencies aiming } \\
\text { at the same } \\
\text { target group } \\
\text { during } \\
\text { programme } \\
\text { selection? }\end{array}$ & $\begin{array}{l}0 \\
(0 \%)\end{array}$ & $\begin{array}{l}14 \\
(24 \%)\end{array}$ & $\begin{array}{l}18 \\
(31 \%)\end{array}$ & $\begin{array}{l}20 \\
(34 \%)\end{array}$ & $\begin{array}{l}6 \\
(10 \%)\end{array}$ & 3,47 & 4,0 & 0,94 & $-0,42$ \\
\hline
\end{tabular}


In Table 7, which is devoted to the selection of the participants for the training, we can see that the CVT specialists hold a positive opinion, since the average in all cases is above 3 . Apart from 3 answers in question 3, there is no other answer "Strongly Disagree". There are very positive indicators in questions 1,2 and 5 , where $50 \%$ of the sample answers above "agree". Furthermore, from the findings in the Table, we could conclude that the interview process and the candidates skills do not consists special and individualised criteria of selection for older people. This could also be traced through the non-existence of a special category or provision for this age group.

\subsubsection{Implementation Analysis}

Table 8: Statistical Parameters for "Implementation"

\begin{tabular}{|c|c|c|c|c|c|c|c|c|c|c|}
\hline & Implementation & $\begin{array}{l}\text { Not at } \\
\text { all }\end{array}$ & $\begin{array}{l}\text { Very } \\
\text { few }\end{array}$ & Enough & $\begin{array}{l}\text { Very } \\
\text { Much }\end{array}$ & $\begin{array}{l}\text { Extre } \\
\text { mely }\end{array}$ & Mean & Median & $\begin{array}{l}\text { Standard } \\
\text { Deviation }\end{array}$ & $\begin{array}{l}\text { Skewness } \\
(\gamma)\end{array}$ \\
\hline 1 & $\begin{array}{l}\text { Up to which extend } \\
\text { does the institutional } \\
\text { framework allow to } \\
\text { take initiatives for the } \\
\text { implementation of the } \\
\text { programmes? }\end{array}$ & $\begin{array}{l}2 \\
(3 \%)\end{array}$ & $\begin{array}{l}16 \\
(28 \%)\end{array}$ & $\begin{array}{l}23 \\
(40 \%)\end{array}$ & $\begin{array}{l}15 \\
(26 \%)\end{array}$ & $\begin{array}{l}2 \\
(3 \%)\end{array}$ & 2,98 & 3,0 & 0,91 & 0,04 \\
\hline 2 & $\begin{array}{l}\text { Up to which extend do } \\
\text { you personally } \\
\text { participate as a CVT } \\
\text { specialist during the } \\
\text { implementation of the } \\
\text { programme with } \\
\text { regard to supervision } \\
\text { of the bureaucratic } \\
\text { procedures? }\end{array}$ & $\begin{array}{l}0 \\
(0 \%)\end{array}$ & $\begin{array}{l}2 \\
(3 \%)\end{array}$ & $\begin{array}{l}15 \\
(26 \%)\end{array}$ & $\begin{array}{l}30 \\
(52 \%)\end{array}$ & $\begin{array}{l}11 \\
(19 \%)\end{array}$ & 3,86 & 4,0 & 0,76 & $-0,26$ \\
\hline 3 & $\begin{array}{l}\text { Up to which extend } \\
\text { do you personally } \\
\text { participate as a CVT } \\
\text { specialist in the } \\
\text { supervision, } \\
\text { evaluation and } \\
\text { guidance of the } \\
\text { educational part? }\end{array}$ & $\begin{array}{l}1 \\
(2 \%)\end{array}$ & $\begin{array}{l}10 \\
(17 \%)\end{array}$ & $\begin{array}{l}13 \\
(22 \%)\end{array}$ & $\begin{array}{l}20 \\
(34 \%)\end{array}$ & $\begin{array}{l}14 \\
(24 \%)\end{array}$ & 3,62 & 4,0 & 1,09 & $-0,36$ \\
\hline 4 & $\begin{array}{l}\text { Up to which extend } \\
\text { do you personally } \\
\text { participate as a CVT } \\
\text { specialist in the } \\
\text { supervision and } \\
\text { evaluation of the } \\
\text { educational process of }\end{array}$ & $\begin{array}{l}1 \\
(2 \%)\end{array}$ & $\begin{array}{l}8 \\
(14 \%)\end{array}$ & $\begin{array}{l}13 \\
(22 \%)\end{array}$ & $\begin{array}{l}19 \\
(33 \%)\end{array}$ & $\begin{array}{l}17 \\
(29 \%)\end{array}$ & 3,74 & 4,0 & 1,09 & $-0,48$ \\
\hline
\end{tabular}


the trainees?

$5 \quad$ Up to which extend do you consider as a

criterion for the

evaluation of

performance of the

training the ability of

the trainees to find $a$

job afterwards?

6 Up to which extent

do you cooperate with

groups and agencies

aiming at the same

target group during

programme

implementation?

As we can see from Table 8, which presents the findings on the implementation of the programmes, there is a differentiation in the answers between question 1 and the rest of them. In question 1, which refers to the institutional framework, the CVT specialists evaluate the level of new initiatives taken as low. With regard to the rest of the questions, the evidence suggests that with reference to procedural issues, the answers range from "enough" to "very much". This is also supported by the negative asymmetry index, where the low extreme observations are to be found at "not at all".

Table 9: t-test for the dependent variable with gender

\begin{tabular}{cccccc}
\hline & Gender & $\boldsymbol{N}$ & Mean & $\begin{array}{c}\text { S andard } \\
\text { Deviation }\end{array}$ & p value \\
\hline \multirow{2}{*}{ Planning } & Male & 32 & 3.14 & 0.43 & \\
& Female & 26 & 3.74 & 0.56 & 0.000 \\
Selection & Male & 32 & 3.11 & 0.4 & \\
& Female & 26 & 3.76 & 0.53 & 0.000 \\
Implementation & Male & 32 & 3.29 & 0.76 & \\
& Female & 26 & 3.78 & 0.01 & 0.024 \\
\hline
\end{tabular}

\subsubsection{Correlation with age}

As we can see below in Table 10, for the dependent variables "planning" and "implementing", differences in correlation to age are statistically significant $(\mathrm{p} .<0.5)$. On the other hand, differences with regard to the selection are not statistically significant. If we observe the averages, we can note that younger participants have a more positive stance towards both of the variables. 
Table 10: Correlation for the dependent variable with age

\begin{tabular}{ccccc}
\hline Variable & Correlation & Planning & Selection & Implementation \\
\hline \multirow{2}{*}{ Age } & $\begin{array}{c}\text { Pearson } \\
(\mathbf{r})\end{array}$ & -0.500 & -0.202 & -0.692 \\
& $\mathbf{p}$ value & 0.000 & 0.128 & 0.000 \\
\hline
\end{tabular}

The negative correlation coefficient suggests that the younger CVT specialists have a more positive stance with regard to issues such as planning and implementation of programmes, since the correlation coefficient $\sim 0.7$ indicates a very strong correlation.

\subsubsection{Correlation with education}

We can see that "planning" and "implementation" differentiate to a significant degree $(p<0.5)$ with regard to the direction of studies, while the differences in the dependent variable "selection" are not statistically significant. From the post-hoc analysis with Bonferonni method, we found that this difference occurs mostly from those who had graduated from the Sciences, as opposed to those who come from Arts, Humanities or Social Sciences background. That is to say that those with a degree in Arts, Humanities, Social Sciences and Business do not differentiate in their opinions about programme planning and implementation. As for the selection of the people participating in the training programmes, not all the specialists differentiate, regardless of their educational background. Overall, they all have in general a positive stance in all three multi-themed units since the average is above 3 (see Table 11).

Table 11: Variance analysis for the dependent variable with education

\begin{tabular}{clcccc}
\hline \multicolumn{1}{c}{ Field of Study } & N & Mean & $\begin{array}{c}\text { Standard } \\
\text { Deviation }\end{array}$ & p value \\
\hline Planning & $\begin{array}{l}\text { Arts \& Humanities } \\
\text { Social Sciences \& } \\
\text { Business }\end{array}$ & 28 & 3.53 & 0.62 & \\
& $\begin{array}{l}\text { Sciences \& Life } \\
\text { Sciences }\end{array}$ & 13 & 3.56 & 0.56 & 0.019 \\
& $\begin{array}{l}\text { Arts \& Humanities } \\
\text { Social Sciences \& }\end{array}$ & 28 & 3.3 & 0.64 & \\
\hline $\begin{array}{l}\text { Business } \\
\text { Sciences \& Life }\end{array}$ & 13 & 3.54 & 0.59 & 0.515 \\
& $\begin{array}{l}\text { Sciences } \\
\text { Arts \& Humanities } \\
\text { Social Sciences \& }\end{array}$ & 17 & 3.42 & 0.38 & \\
Business & 28 & 3.79 & 0.79 & 0.014 \\
& $\begin{array}{l}\text { Sciences \& Life } \\
\text { Sciences }\end{array}$ & 13 & 3.49 & 0.74 & \\
\hline
\end{tabular}




\subsubsection{Correlation with postgraduate studies}

As Table 12 shows, in the planning and implementation unit, the specialists who hold a postgraduate degree are more confident and have a more positive stance.

Table 12: Level of education

\begin{tabular}{cccccc}
\hline \multirow{2}{*}{ Planning } & $\begin{array}{c}\text { Postgraduate } \\
\text { Degree }\end{array}$ & N & Mean & $\begin{array}{c}\text { Standard } \\
\text { Deviation }\end{array}$ & p value \\
\hline \multirow{2}{*}{ Selection } & No & 32 & 3.23 & 0.55 & 0.005 \\
& Yes & 26 & 3.64 & 0.52 & \\
Implementation & No & 32 & 3.34 & 0.51 & 0.365 \\
& Yes & 26 & 3.48 & 0.63 & \\
& No & 32 & 3.24 & 0.73 & 0.003 \\
\hline
\end{tabular}

\subsubsection{Correlation with professional experience}

Below in Table 13 we observe that in planning and implementation of the programmes we can find a statistically significant relationship with regard to the sample's experience. This correlation between the independent variable "educational and professional experience" and "implementation" is negative in all cases and it is strong enough in only two cases. In the cases where Pearson's $r$ is between $|0.3-0.6|$ then the correlation is not very strong, meaning there are other factors that have an impact on the creation of the opinion and stance towards the dependent variables of the multi-themed unit. The existence of a negative correlation, as said before, would suggest that the less experience the specialists have, the more positive stance towards the dependent variables "planning" and "implementing" they would have. At this point, it should also be noted that older specialists tend to have more consolidated opinions, which may be the result of their many years experience that does include difficult past situations in planning and implementing programmes under the lack of supporting structures.

Table 13: Correlation with professional experience

\begin{tabular}{ccccc}
\hline Variables & Correlation & Planning & Selection & Implementation \\
\hline $\begin{array}{c}\text { Educational } \\
\text { Experience }\end{array}$ & $\begin{array}{c}\text { Pearson } \\
(r)\end{array}$ & -0.46 & -0.16 & $\mathbf{- 0 . 6 9}$ \\
$\begin{array}{c}\boldsymbol{p} \text { value } \\
\text { Pearson }\end{array}$ & 0.000 & 0.230 & $\mathbf{0 . 0 0 0}$ \\
$\begin{array}{c}\text { Experience } \\
\text { Professional }\end{array}$ & $\begin{array}{c}\boldsymbol{p} \text { v value } \\
\text { Pearson } \\
(r)\end{array}$ & -0.37 & -0.13 & $\mathbf{- 0 . 6 1}$ \\
$\begin{array}{c}\text { Experience with Older } \\
\text { People }\end{array}$ & $\begin{array}{c}\boldsymbol{p} \text { value } \\
\text { Penal }\end{array}$ & 0.000 & 0.320 & $\mathbf{0 . 0 0 0}$ \\
\hline
\end{tabular}




\section{Conclusions}

It is worth to note some specific findings. Initially, it seems that most active CVTs are private. This indicates that almost fifteen years after their establishment public sector CVTs were not able to acquire the desired dynamic. General reasons for this could be attributed to problems relevant with coordination, lack of resources and overlap that are endemic to the public sector. Another important information is that women do participate in this field equally well with men. This study reaffirms the active introduction of women in high-level executive positions that entail both risk and crucial decision-making.

With regard to educational background and their respective field of study, although the data do not indicate any significant divergence, they do suggest that there should be established an institutional framework under which specific schools and departments related to adult education and continuous education should be prioritised. Furthermore, the state should create motives for an objective institutionalised education in this field of study. For example, the certificates of educational sufficiency, established as necessary formal requirement in other scientific fields not having in their curriculums an educational dimension, in order to teach in standard education, should serve as an example for the establishment of something similar in the workplace, where adult education, continuous training and life long learning are fundamental.

Furthermore, the CVT specialists, who are adults themselves and they do consider crucial their overall professional experience, they do not neglect the importance of educational experience and the need for the acquisition of such form of experience. On the other hand, they do accept the fact that older individuals do not have a specific educational and professional experience. Although a large number of them have attended some form of educational training for continuing education trainers, they still do not have any specific training on the age group 50-65. This fact is alarming, since international institutions pay much attention to the phenomenon of the active ageing of the population, by taking measures and adopting policies to combat work exclusion and social exclusion that are even more prominent.

Finally, with regard to the duties of the organised state, it should definitely utilise the experience of people such as the CVT specialists in planning and implementing of these training programmes, since they express an experiential opinion through their everyday contact with this issues and the overall planning. Therefore, their evaluation reports should be taken under deeper consideration and not only be treated as part of their formal bureaucratic duty. 


\section{References}

Bangemann, M. (1994). Europe and the global information society. Recommendations to the European Council. E.C.: Brussels.

Barnes, M. (2002). Social exclusion and the life course. In Barnes, M., Heady, C., Middleton, S., Millar, J., Papadopoulos, F., Room, G., \& Tsakloglou, P. Poverty and Social Exclusion in Europe (pp.1-23). Cheltenham,UK• Northampton, MA, USA: Edward Elgar.

Bennell, P. (1999). Learning to Change: Skills development among the economically vulnerable and socially excluded developing countries. Employment and Training Papers. Geneva: ILO.

Boutsiouki, S. (2006). Formation and development of educational policies in the EU and changes in the workplace: an evaluative approach to IVT. Thessaloniki: Same.

Brandsma, J. (2005). Social exclusion and equality in education. The European Commission.

CEDEFOP (2002). Vocational Education and Training in Greece. Luxembourg.

CINTERFOR (2001). Training for decent work. Montevideo: Cinterfor/ILO.

Duke, C. (1989). Training of adult educators. In Titmus, C. J. (Ed.), Lifelong Education for Adults: an International Handbook (pp.360-367). Oxford: Pergamon Press.

E.E.D.E., 2007. Study on the initiatives of European and international organizations on the management of active aging, OFFICERS TRAINING SEMINAR "Current policies for effective management of active aging workforce", Athens: INE / GSE

Efstratoglou, A. (2003). Ongoing training and certification. VCT process and results 2001 to 2003. Athens: National Accreditation Centre of Vocational Training Structures and Accompanying Support Services.

Georgiakodis, M., \& Tzanetou F. (2002). Vocational Education and Training in Greece. Athens: E.KE.PIS.

Gklavopoulos, E. (2007). Professional Training and Active Aging. Katartizein, 18.4.

Glavopoulos, E. (2006). Quality and S.E.K. Katartizein, 11, 14-15.

Gouvia, D. (2003). Lifelong learning? Thanks, I will not get!. The importance of creating a "demand" for adult education using information technology and communications. In: Sociology: Lesson freedom. Proceedings of the 2nd International Congress of Sociology, Thessaloniki, 8-10 November 2002.

IOBE. (2006). Issue bibliographic study concerning the management of active aging, Athens: Same.

Jarvis, P. (1995). Adult and Continuing Education. Theory and Practice (2nd ed.). London and New York: Routledge. 
Jarvis, P., \& Chadwick, A. (1994). Training of Adult Educators. In Husen, T. \& Postlethwaite, T. N. (Eds.), The International Encyclopedia of Education (2nd ed.). (Vol.11, pp. 6431 6438). Oxford: Pergamon.

Karalis, T. (2005b). The training of unemployed teachers in the reports, current status and perspectives. Adult Education, 5, 9-14. Continuing Vocational Training System in the period 1994 to 2004. In Valanidis, G. (Ed.), Training and professional development of teachers (pp. 334-339). Athens: Metaixmio.

Kazamias, A. (2005). Globalization and educational cultures in late modernity: the syndrome of Agamemnon. In: Gravaris, D. - Papadakis, N. (Eds.), Education and educational policy. Between state and market. Athens, Savalas, 94-96.

Knowles, M., Holton, E. F., \& Swanson, R. A. (1998). The Adult Learner: The definitive classic in Adult Education and Human Resource Development (5th ed.).Huston, Texas: Gulf Publishing.

Kokkos, A. (2003). The transformation of attitudes and the role of animator. In Vergidis, D. (Ed.), Adult Education. Contribution to trainers and staff expertise (ss.195-223). Athens: Greek Letters.

Kokkos, A. (2005a). Methodology of Adult Education. Patras: Hellenic Open University.

Kokkos, A. (2005b). Adult Education: Tracing the field. Athens: Metaixmio.

Kostaridis-Efkleidis, A. (1997). Psychology incentives. Thessaloniki: Art of Text.

Kotsiki, B. (1994). Vocational education and training, organization and administration of vocational education and training. Athens: Greek.

Koukiadis, J. (2008). Active aging, flexible work and workers over 55. Experience Development.

Koutsonikos, G., \& Katsigiannis, M. (2003). The role of the Internet in informing managers and adult educators. In Vergidis, D. (Ed.), Adult Education. Contribution to trainers and staff expertise (ss.51 - 62). Athens: Greek Letters.

Levitas, R. (1998). The inclusive society? Social exclusion and New Labour. Basingstoke: Macmillan.

Martin, B. (1981). A Sociology of Contemporary Cultural Change. Oxford: Basil Blackwell.

McFadzean, E. (2001a). Supporting virtual learning groups. Part 1: a pedagogical perspective. Team Performance Management: An International Journal, 7 (3/4), pp. 53-62.

Mee, G., \& Wiltshire, H. (1978). Structure and Performance in Adult Education. London: Longman.

Ministry of Economy and Finance - Employment and Social Protection (Official Gazette 230/21.2.2005). System Certification Training Centres (VTC). 
Papaioannou, E. (2004). Changing attitudes to education. . O World of Vocational Training, 2, 7.

Pieck, E. (2005). Work-related adult education: challenges and possibilities in poverty areas. INT. J. OF LIFELONG EDUCATION, VOL. 24, NO. 5 (SEPTEMBER-OCTOBER 2005), 419-429. Mexico: Universidad Iberoamericana.

Pleios, G. (1999). Education, employment and social exclusion. In

Constantinou, C., and Pleiades, G. (Ed.), School failure and social exclusion: Causes, consequences and treatment. Proceedings of The International Scientific Conference (ss.333-363). Athens: "Greek Letters" - Educational Society.

Psarou, M., \& Zafiropoulos, K. (2003). Scientific Research: Theories and applications in social sciences. Athens: Typotheto.

Psimitis, M. (2002). Introduction. In: Meloutsi, A. (M. Psimitis mtf), Cultures in the game. differences to live together. Athens, Gutenberg.

Raptis, A., \& Rapti, A. (2003). Learning and teaching in the information age. Total approach (vol). Athens: Raptis.

Robolis, S., \& Dimoulas, K. (1998). Partnerships in tackling social exclusion. In Cassimatis, K. (Ed.), Social exclusion: the Greek experience (ss.151-189). Centre for Social Morphology and Social Policy. Athens: Gutenberg.

Room, G. (2000).Trajectories of social exclusion: the wider context for the third and first worlds. In Gordon, D., \& Townsend, P. (Eds), Breadline Europe (pp.407- 439).Bristol: Policy Press.

Room, G. (Ed.) (1995). Beyond the Threshold: The Measurement and Analysis of Social Exclusion. Bristol: Policy Press.

Streuner, J. N. \& Tuijnman, A. C. (1994). Curriculum in Adult Education. In Husen, T. \& Postlethwaite, T. N. (Eds.), The International Encyclopedia of Education (2 $2^{\text {nd }}$ ed.). (Vol. 3, pp.1308-1315).Oxford: Pergamon.

Tsiakalos, G. (1998). Social Exclusion: Definitions, scope and importance. In Cassimatis, K. (Ed.), Social exclusion: the Greek experience (ss.39-65). Centre for Social Morphology and Social Policy. Athens: Gutenberg.

Tsiolis, G. (2005). Work and training in planning the new biography. A micro-sociological approach. In: Gravaris, D. - Papadakis, N. (Eds.), Education and educational policy. Between state and market. Athens, Savalas, 462.

Vaina, K., \& Economou, A. (2007). What, Why, How, Where, When. Five questions for the Adult Educator. Katartizein, 16,5-7.

Vergidis, D. (2002). Continuing Professional Development as a social investment. Hellenic Association of Companies in Vocational Training Centers. Vocational Training and 
Employment in Greece: Proceedings 1st International Conference EL.S.E.K.E.K. (Athens, 17-18 May 2002): Mapping of KEK.

Vlahos, S., \& Kyritsis, K. (2003). Social exclusion. Vulnerable groups. Athens: Infocus.

Vleminckh, K., \& Berghman, J. (2001). Social exclusion and the welfare state: an overview of conceptual issues and policy implications. In Mayes, G., Berghman, J., \& Salais, R. (Eds.), Social Exclusion and European Policy (pp. 27-46). UK: Edward Elgar.

Walker, A., \& Walker, C. (1997). Britain Divided: The Growth of Social Exclusion in the 1980s and 1990s. London: CPAG.

\section{Copyright Disclaimer}

Copyright reserved by the author(s).

This article is an open-access article distributed under the terms and conditions of the Creative Commons Attribution license (http://creativecommons.org/licenses/by/3.0/). 